\title{
日本茶業技術協会・技術賞（昭和62年度）内容の紹介
}

\section{The Japan Tea-Technicians' Association : Introduction of Technical Prizes for Research Investigations}

\author{
Pestalotia longiseta Spegazzini によるチャ輪斑病, \\ 新梢枯死症の発生生態と防除法の確立に関する研究
}

静岡県茶業試験場 堀 川知廣

チャ輪斑病はPestalotia theae SAWADAによって起

こるとされていたが，一般の茶園で発生することは きわめてまれであり，防除対象病害とされていなか った。しかし，1970年代の初めから，静岡県の西 部地域のやぶきた園において激しい枝枯れをともな 万輪斑病が発生しはじめ, 徐々に静岡県内各地や, 隣接した他府県でも多発茶園がみられるよらになっ た。このような茶園から発病葉を採集し，病原菌を 分離し同定した結果，今までにチャ輪斑病菌として は記載のないPestalotia longiseta Speg. が病原菌で あることが明らかとなった。そこで，P. longiseta の感染生態, 防除法について研究を進めた。

P. longiseta のチャへの感染時期は二つに大別で きる。一つは摘採や整枝の作業時であり，むら一つ は新芽の生育初期である。前者では，葉や茎に生じ た切断部に分生子が付着，感染して，いわゆる「輪 斑病葉」や茎の枯机込みが生じ，後者では成熟した 新梢が基部から枯死する「新梢枯死症」が生じる。

感染に影響を及注す環境条件としては，まず第一 に温度があげられる。P. longiseta の発芽や菌系の 生有は $25^{\circ} \mathrm{C} \sim 30^{\circ} \mathrm{C}$ が啇温であるため, 輪斑病は二, 三番茶摘採後に多発しやすく，新梢枯死症は三番茶 芽や秋芽の生育初期に感染しやすい。

一般に病害の感染は降雨や水滴の有無が大きく影 響するが，P. longisetaの場合には輪斑病と新梢枯 死症では水滴の影響が大きく異なる。すなわち，新 梢枯死症に打いては，新芽の萌芽から開葉期に降雨 があると発生が著しく多くなるが，輪斑病では摘採 時に茶葉が濡れていたり，摘採直後に降雨があった 場合においても発病程度はあまり増加しない。

気温, 水滴のほかに, 感染を助長する要因として は，輪斑病では摘採の方法があげられ，可搬型摘採 機を用いた摘採は，他の摘採方法に比較し，感染率
が高くなる。

品種間差異はきわめて顕著であり，やぶきた，さ やまみどりの 2 品種がり病性であるがその他の品種 は，発病程度が低く栽培上防除の必要はない。

輪斑病が激しく発生すると発病後の新芽の生育は 著しく抑制されるが，発病後周到な管理を行なえば 越冬期までにはぼ回復して，発病翌年の一番茶の収 量にはほとんど影響しない。しかし，2 年続けて発 生すると樹勢が低下して，一番茶が減収する。新梢 枯死症が発生した場合においても同様のことが言え るが，秋芽に新梢枯死症が発生すると，輪斑病に比 較し，一番茶への影響は大きい。

防除法は輪斑病と新梢枯死症では異なる。輪斑病 に有効な薬剂としては，トップジンM水和剤, ベン レート水和剤, ダコニール水和剤, カスミンボルドー 水和剤などがある。これらの薬剂は摘採直後に散布 すれば効果が高いが，摘採後時間の経過とともに効 果が低くなる。新梢枯死症に有効な薬剤としては, 上記 4 用のほかに，ベフドー水和剤などがあり，新 芽の萌芽から開葉期にかけて1〜2回散布すれば実 用的な防除効果が得られる。しかし，ベンレート水 和剂，トップジンM水和剂に対しては現在耐性の菌 が広く分布し，両薬剤は効果が不安定である。この 両薬剤はP. longisetaにたいして卓効を示すが，耐 性菌と感受性菌の病原力を比較した結果, 前者の方 がやや強い傾向があるのでこれら両薬剤が近い将 来再び使用できるようになることは期待できない。

$P$. longiseta に寄生し，分生子を不活化する輪斑 病菌の病原菌としてStreptomyces roseosporus を分 離した。実験室レベルでの生物活性は高いので，今 後，固場での生物的防除に利用できるか否か調查研 究を進めたい。 


\section{発表文献，疽料}

1）堀川知廣：茶業技術研究発表会講要集，p. 10 (Feb., 1979) (講要).

2）堀川知廣: 関西病虫研報, No. 22, 69（1980）。

3）堀川知廣：日植病報, 46(1), 107 (1980) (講要)。

4）堀川知廣: 茶研報, No. 51,84 (1980) (講要)。

5）煀川知廣：茶研報, No. 53，81 82（1981）（講 要).

6）堀川知廣: 茶研報, No. 56, 45 56（1982）。

7）堀川知廣：茶研報, No. 55, 113 114（1982） (講要).

8）浜屋悦次，堀川知廣：茶技研，No. $62 ， 21 \sim 28$ (1982).

9）堀川知廣：あたらしい農業技術，静岡県農業水 産部, No.74 (1982).

10）堀川知廣：関西病虫研報, No. $24 ， 62$ (1982) (講要).

11）堀川知廣: 茶研報, No. 57, 18 25（1983）.

12）堀川知廣 : 茶研報, No. $57,69 \sim 70$ (1983)（講 要).

13）堀川知廣: 日植病報, 49(3), 401 (1983) (講要).

14）堀川知黄 : 関西病虫研報No. 25，56（1983）（講 要).

15) Horikawa, T., : Fourth international congress of plant pathology, Melbourne, Australia, p. 226 (1983).

16）堀川知廣: 茶研報, No. 59, 60 (1984) (講要).
17）堀川知廣 : 日植病報, 50(1), 186 (1984) (講要).

18）堀川知廣：日植病報, 50(3)，409 (1984) (講要).

19）煀川知廣：植物防疫，38(6)，275 279 (1984).

20）堀川知廣：茶研報，No.61，62６3（1985）（講 要).

21）煀川知廣：茶研報，No. 62，52 54（1985）。

22）堀川知廣: 日植病報, 52(1), 145 (1986) (講要)。

23) Horikawa, T., : Fourth international symposium on the microbiology of the phyllosphere, Wageningen, p. 30 (1985).

24）堀川知廣 : 茶研報, No. 63，66～67（1986）（講 要).

25）堀川知廣：静岡茶試研報, No. 12, 1 8 (1986) 。

26）堀川知廣: 静岡茶試研報, No. 12, 9 14 (1986).

27）堀川知廣: 静岡茶試研報, No. 12, 15 22 (1986).

28）堀川知廣：日植病報，52(5)，766７71（1986）。

29）堀川知廣：日植病報, 52(5), 858 859 (1986).

39）堀川知廣 : 茶研報, No. $65,38 \sim 45$ (1987).

31）堀川知廣: 茶研報, No. 65，46〜54 (1987).

32）堀川知廣: 茶研報, No. 65, 55 60（1987）.

33）堀川知廣：茶研報, No. 65, 110 111（1987） (講要).

34）堀川知廣: 日植病報, 53(1)，69 (1987) (講要).

35）堀川知廣：日植病報, 53(1)，116 (1987) (講要)。

36) 堀川知廣: 日植病報, 53(3), 387 (1987) (講要).

37）堀川知廣: 関西病虫研報No. 29, 21 26 (1987). 